Original Research

\title{
Quantifying the Generated and Percolated Leachate through a Landfill's Lining System in Gaza Strip, Palestine
}

\author{
Taher Abunama ${ }^{1}$, Faridah Othman ${ }^{1}$, Tamer Alslaibi ${ }^{2}$, Motasem Abualqumboz ${ }^{3}$ \\ ${ }^{1}$ Department of Civil Engineering, University of Malaya, 50603, Kuala Lumpur, Malaysia \\ ${ }^{2}$ Department of Civil Engineering, University of Palestine, Gaza Strip, Palestine \\ ${ }^{3}$ Department of Civil Engineering, University of Petronas, Perak, Malaysia
}

Received: 12 March 2017

Accepted: 15 May 2017

\begin{abstract}
Landfills are one of the main soil and groundwater pollution sources in Gaza Strip/Palestine. By addressing Deir Al Balah landfill, this study aims to quantify the generated and percolated leachate quantities through the landfill's lining system toward the groundwater aquifer. Leachate volumes have been quantified using two different approaches, namely the hydraulic evaluation of landfill performance (HELP) model and the water balance method (WBM), and then compared with the measured quantities by the landfill's management. Results of the HELP model showed that the average annual generated leachate volumes were $8,087 \mathrm{~m}^{3}$ from 1997 to 2014, while the average annual percolated leachate volumes were $717 \mathrm{~m}^{3}$, which represented $8.9 \%$ of the generated leachate amounts. However, WBM results for the average annual leachate during the same period were $7,568 \mathrm{~m}^{3}$. The landfill's leachate was mainly originated from the moisture content of the dumped wastes, whereas the rest came from the infiltration of the rainfall and re-circulated leachate. The cumulative modelled leachate amounts by HELP model and WBM were close, and with a difference percentage of $6.6 \%$. However, both methods' results were higher than the measured leachate amounts. In conclusion, suitable mitigation measures are required to minimise the potential threats on to groundwater due to leachate percolation.
\end{abstract}

Keywords: landfill leachate, HELP model, water balance method (WBM), soil and groundwater pollution, Deir Al Balah landfill

\section{Introduction}

Waste landfilling is still the most dominant and viable method for waste disposal all over the world. Due to its economic advantages, it has been used for disposal of nearly all waste types, especially in developing countries.

*e-mail: tabunama@hotmail.com
As a consequence of the waste degradation process in landfills, highly polluted leachate and gases are produced in huge quantities, which may gradually be released to surrounding ecosystems.

Even the development of landfilling technologies from uncontrolled dumpsites to sanitary landfills still represents potential threats to the environment [1]. In recent decades, numerous studies have highlighted the associated social and environmental risks imposed by landfill leachate, 
which is related to its highly contaminated pollutants and heavy metals and which can deteriorate the quality of the surrounding surface water bodies and groundwater aquifer [2]. Additionally, the unseparated municipal solid wastes (MSW) may include industrial, medical, and hazardous wastes; therefore, the released leachate tends to contain high toxic constituents and heavy metals [3].

In general, landfill leachate characteristics and volumes are highly varied, and mainly depend on several factors such as wastes composition and its moisture content, disposal method, landfill age, and climatological conditions. The high moisture content of the dumped wastes - especially in developing countries - results in high water storage in landfills, which enhances the accumulation of acids. As a consequence, the carbon-based substances in such acidic landfills tend to be decomposed to leachate rather than released as gases [4].

The evaluation of landfill leachate quality and quantities is essential for assessing its environmental impact, as well as for treatment and management purposes. The factors that influence the leachate production process vary in time and space, hence the evaluation process becomes more difficult and complex [1].

The first attempt to quantify the generated leachate amounts using a simplified water balance method (WBM) was introduced by many researchers, including El-Fadel et al. [5]. Based on the same concept of WBM, several mathematical models and equations have been developed in the last decades, which are varying in prediction complicity and accuracy.

Among them, the hydrologic evaluation of landfill performance (HELP) model is the most-used tool by engineers and designers. The HELP model was developed

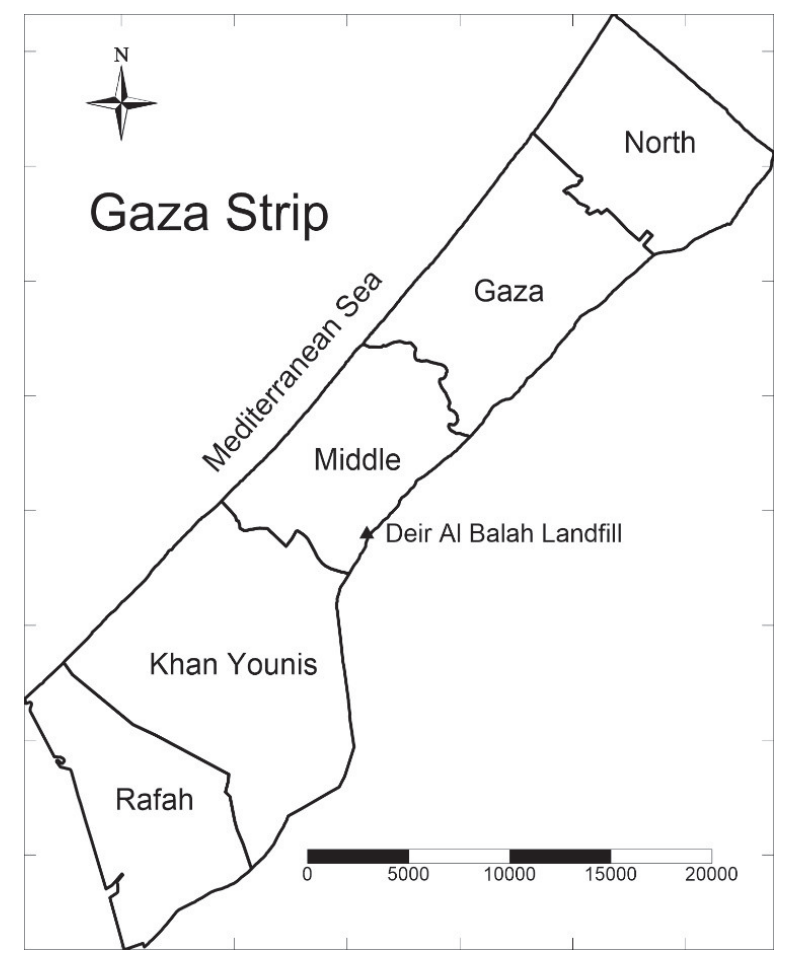

Fig. 1. Location of Deir Al Balah landfill in Gaza Strip. to evaluate a landfill's hydrological performance [6], and it has been used in different studies recently [7-8]. For the sake of accuracy and verification purposes, other researchers used both the HELP model and WBM method in the same case study, such as Alslaibi et al. [9].

In the Gaza Strip, Deir Al Balah landfill exceeded its maximum capacity many years ago, and huge waste quantities are still being dumped. Therefore, it is crucial to quantify the generated and percolated leachate amounts into the soil layers toward the groundwater aquifer. Such a study can help the concerned authorities and researchers in further assessments and in applying suitable control and mitigation measures.

\section{Study Area}

Gaza Strip (GS) is located in the southwestern part of the Palestinian coastal plain along the Mediterranean Sea. Total area of GS is about $365 \mathrm{~km}^{2}$, with a length of $41 \mathrm{~km}$ and width of about $6-12 \mathrm{~km}$ (Fig. 1). The strip's climate is considered semi-arid, where the average annual rainfall is around $342 \mathrm{~mm}$. In 2007 the daily generated wastes from GS were more than 1,500 tons and it is projected to reach about 3,700 tons per day by 2040 [10].

As reported by Alqader et al. [11], the main fraction of GS MSW composition is organic matter (52\%), while the other components are paper $(11 \%)$, metals $(3 \%)$, glass $(3 \%)$, and miscellaneous wastes $(18 \%)$. However, the organic wastes range from $60-70 \%$, according to other studies [10, 12-13].
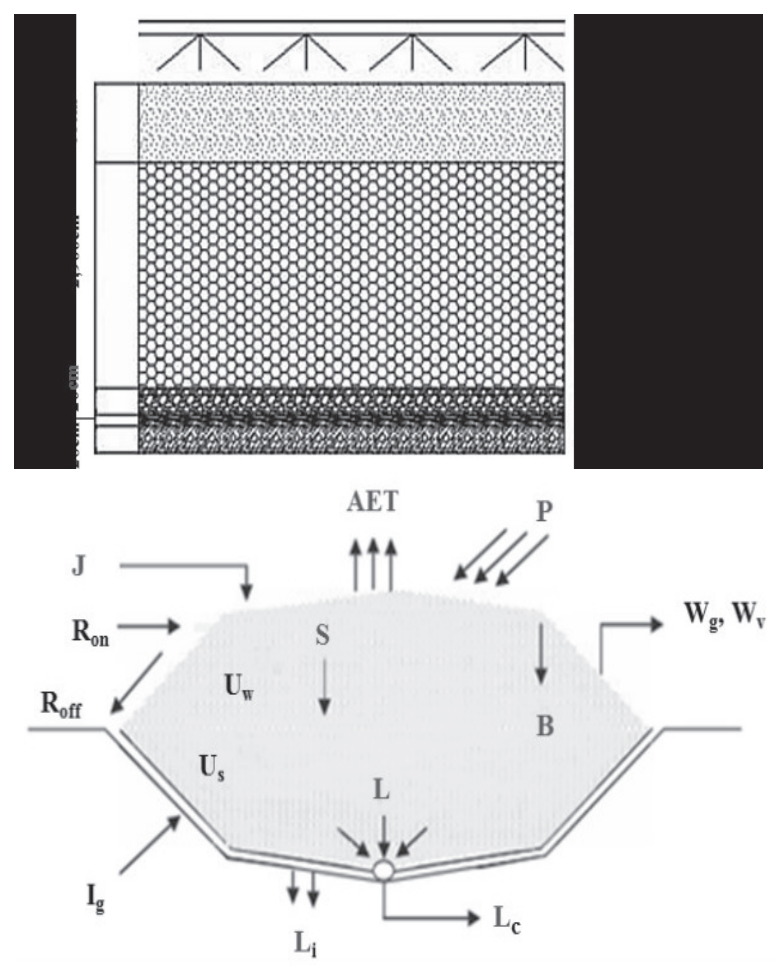

Fig. 2. Deir Al Balah landfill's lining system and typical water balance functional elements $[14,16]$. 
Table 1. Summary of HELP model data entry [18].

\begin{tabular}{|c|c|c|c|}
\hline Data Category & Parameter & Unit & Time step \\
\hline \multirow{8}{*}{ Climate data } & Precipitation & $\mathrm{mm}$ & Daily \\
\hline & Solar radiation & $\mathrm{MJ} / \mathrm{m}^{2}$ & Daily \\
\hline & Temperature & ${ }^{\circ} \mathrm{C}$ & Daily \\
\hline & Relative humidity & $\%$ & Seasonally \\
\hline & Average wind speed & $\mathrm{km} / \mathrm{hr}$ & 10.92 \\
\hline & $\begin{array}{l}\text { Maximum leaf area } \\
\text { index }\end{array}$ & - & 3.5 \\
\hline & $\begin{array}{c}\text { Evaporation zone } \\
\text { depth }\end{array}$ & $\mathrm{cm}$ & 23.62 \\
\hline & Runoff curve number & - & 81.3 \\
\hline \multirow{8}{*}{$\begin{array}{c}\text { Landfill design } \\
\text { data } \\
\text { and layers } \\
\text { characteristics }\end{array}$} & Area & Hectares & 6 \\
\hline & $\begin{array}{l}\text { Leachate recycling } \\
\text { ratio }\end{array}$ & $\%$ & 40 \\
\hline & Layers thicknesses & $\mathrm{cm}$ & \multirow{6}{*}{ Table (2) } \\
\hline & Total porosity & vol./vol. & \\
\hline & Field capacity & vol./vol. & \\
\hline & Wilting point & vol./vol. & \\
\hline & Moisture content & vol./vol. & \\
\hline & $\begin{array}{l}\text { Hydraulic } \\
\text { conductivity }\end{array}$ & $\mathrm{cm} / \mathrm{sec}$ & \\
\hline
\end{tabular}

This study is focused on Deir Al Balah landfill at the eastern border of the middle governorate of GS. The total area of the landfill is about $60,000 \mathrm{~m}^{2}(400 \mathrm{~m} \times 150 \mathrm{~m})$ and with average height of $29 \mathrm{~m}$. According to MDLF [10], the landfill receives around 100,000 tons of waste per year from 13 municipalities and villages in the Khan Younis and Middle governorates.

Deir Al Balah landfill has been in operation since 1997, and it includes a scale house, warehouse, screening plant, and two leachate bonds [14]. In addition, the landfill's lining system consists of five layers, namely (from the bottom) base: course, asphalt, aggregate, wastes, and clay cover (Fig. 2). The landfill's leachate is channeled to two leachate ponds through a gravity drainage system, and $40 \%$ of the collected leachate is re-circulated by spreading it on the top wastes.

\section{Materials and Methods}

Two different approaches were used to quantify the generated leachate from Deir Al Balah landfill, namely the HELP model and WBM. In both approaches, the available meteorological data from the nearest recording station were utilized, which included precipitation, evapotranspiration, temperature, and solar radiation, etc. In the following sections, the applied methodology in the two approaches and the required input data were listed:

\section{HELP V3.07 Model}

HELP is a quasi two-dimensional hydrological model of water movement to, through, and out of landfills [15]. It was developed by the U.S. Environmental Protection Agency (US EPA) in order to evaluate the hydrological performance of landfills in specific climatic conditions.

HELP applies different empirical and numerical equations in evaluating landfill leachate. For instance, runoff estimation is performed by the soil conservation service (SCS) curve number (CN) method, while evapotranspiration is computed by the modified Penman method. These processes and others are applied in a sequential order on a daily basis, starting with a surface water balance at the landfill's surface, followed by an estimation of evapotranspiration, and lastly, the drainage of leachate water through the landfill's layers [15].

In this study, the evaluation of Deir Al Balah landfill leachate was performed by HELP for an 18-year simulation period (1997-2014). The meteorological data included a daily set of precipitation, evapotranspiration, and temperature, while solar radiation was assigned seasonally. In addition, landfill design and operation parameters, such as landfill layers, slopes, final cover, and the dumped waste characteristics, are summarized in Tables 1 and 2.

\section{WBM}

WBM is a simple mathematical calculation between the water inputs and outputs of a landfill, which can be carried out by summing the water amounts that percolate to a landfill's body with the water content of the

Table 2. Layer types and typical properties.

\begin{tabular}{|c|c|c|c|c|c|c|}
\hline \multirow{2}{*}{ Layer parameters } & \multirow{2}{*}{ Unit } & Layer 1 & Layer 2 & Layer 3 & Layer 4 & Layer 5 \\
\cline { 3 - 7 } & & Clay cover & Waste & Aggregate & Asphalt & Base course \\
\hline Thickness & $\mathrm{cm}$ & 60 & 2400 & 20 & 9 & 20 \\
\hline Total porosity & vol./vol. & 0.437 & 0.671 & 0.37 & 0.427 & 0.37 \\
\hline Field capacity & vol./vol. & 0.062 & 0.292 & 0.032 & 0.418 & 0.032 \\
\hline Wilting point & vol./vol. & 0.024 & 0.077 & 0.013 & 0.367 & 0.013 \\
\hline Moisture content & vol./vol. & 0.0835 & 0.294 & 0.033 & 0.427 & 0.033 \\
\hline Hydraulic conductivity & vol./vol. & $5.8 \times 10^{-2}$ & $10-3$ & 0.3 & $1 \times 10^{-7}$ & 0.3 \\
\hline
\end{tabular}


dumped wastes, then abstracting the lost water by waste degradation, gas generation, etc. (Fig. 2) [16].

In this study, a number of assumptions were applied to derive and simplify the WBM equations. These assumptions were based on the landfill's managers, including:

- The water entering the landfill is assumed to be only from rainfall, because the landfill is located far from any surface water bodies

- The landfill's site topography is situated on a relatively high ground compared with the surrounding lands; therefore, the water amount entering from the surface runoff is assumed to be low and can be neglected $($ Ron $=0)$

- No water contribution is due to the raising of the aquifer table, which is about $40 \mathrm{~m}$ below the base of the landfill [13]

- The consumed water during waste biodegradation and gas formation is assumed to be insignificant

Therefore, water infiltration $(I)$ from the landfill surface can be calculated by the following equation [17]:

$$
I=P-E-R o f f
$$

...where $I$ is the water amount entering the waste body $\left(\mathrm{m}^{3}\right), P$ is precipitation $\left(\mathrm{m}^{3}\right), E$ is evaporation $\left(\mathrm{m}^{3}\right)$, and Roff is the surface runoff from the landfill $\left(\mathrm{m}^{3}\right)$.

The percolated water to the landfill is subjected to be absorbed by the dumped wastes until reaching the landfill's field capacity $(F C)$, which can be defined as the maximum water quantities that can be held in the waste body against the pull of gravity. As a result, excess water leaches and moves toward the landfill's sides and bottom.

The landfill's leachate (L) movement is assumed to occur only under saturated conditions, when the infiltrated water and the dumped wastewater content surpasses the landfill's field capacity, as illustrated by the following equation:

$$
L=I+W_{m}-F C
$$

... where $W_{m}$ is the water content in the dumped wastes and $F C$ is the landfill's field capacity.

WBM calculations are illustrated in the following steps:

- Analyse the available meteorological data, including precipitation $(P)$ and evaporation $(E)$, etc.

- Calculate the surface runoff (Roff): Roff $=C_{R} \times P$, where $C_{R}$ is the surface runoff coefficient.

- Calculate the water infiltration $(I)$ to the landfill: $I_{1}=P-E-$ Roff.

- Calculate the actual water content (Store $)_{1}$ inside the landfill due to rainfall and the water content of the dumped wastes: Store $_{1}=I_{1}+W_{m}$.

- Calculate the landfill's field capacity: $F C=D W x$ $F C \%$, where $D W$ is the dry weight of the dumped wastes.

- Calculate the generated leachate: $L_{1}=$ Store $_{1}-F C$; if Store $_{1}>F C$, leachate can be formed; otherwise,

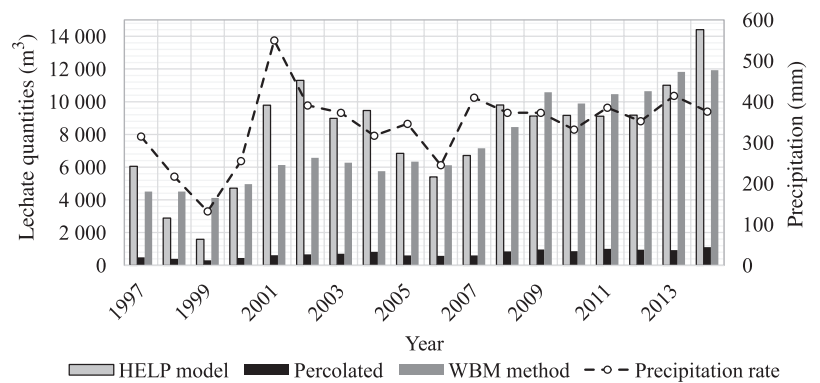

Fig. 3. Annual leachate generation and percolation through the landfill's lining system versus annual precipitation rates.

a moisture deficit occurs and there is no leachate formation.

- Calculate the penetration portion $\left(\mathrm{I}_{2}\right)$ of the recirculated leachate $\left(\mathrm{RL}=L_{1} * 40 \%\right): I_{2}=R L-E_{2}$, where $\mathrm{E}_{2}$ is evaporation in volumes $\left(\mathrm{m}^{3}\right)$ throughout the year.

- Calculate the generated leachate with recirculation $\left(L_{2}\right): L_{2}=$ Store $_{2}-F C$, where Store $_{2}$ is the sum of Store ${ }_{1}$ and $I_{2}$.

\section{Results and Discussion}

Leachate quantities were estimated by HELP model and WBM in the landfill from a period of 18 yrs. (1997-2014), and with a recycling ratio of $40 \%$. Fig. 3 presents the annual rainfall rate versus the annual generated leachate by both methods, as well as the percolated leachate through the lining layers by the HELP model.

The average annual rates and volumes of the landfill hydrological water budget by the HELP model are illustrated in Table 3. Hence the average annual generated leachate amounts through 18 years were $8,087 \mathrm{~m}^{3}$, which represent about $39.4 \%$ of the total precipitation $\left(60,000 \mathrm{~m}^{2} \times 342.1 \mathrm{~mm}\right)$. Also, the average surface runoff portion was about $6.8 \%$ of the total precipitation, and it counted of $1,396 \mathrm{~m}^{3}$ year $^{-1}$.

However, evapotranspiration was the highest fraction in the landfill water budget, since the landfill is located in a semi-arid region. Evapotranspiration amounts reached approximately $11,042 \mathrm{~m}^{3}$ per year (53.8\% of precipitation) through the study period (1997-2014). A close ratio was estimated by Alslaibi [9], where the modelled

Table 3. Average annual rates and volumes of water budget components (HELP model).

\begin{tabular}{|c|c|c|c|}
\hline Component & $\begin{array}{c}\text { Avg. rate } \\
(\mathrm{mm})\end{array}$ & $\begin{array}{c}\text { Avg. } \\
\text { volume }\left(\mathrm{m}^{3}\right)\end{array}$ & $\begin{array}{c}\text { Percentage } \\
(\%)\end{array}$ \\
\hline Precipitation & 342.1 & 20,525 & 100 \\
\hline Evapotranspiration & 184.0 & 11,042 & 53.8 \\
\hline Runoff & 23.3 & 1,396 & 6.8 \\
\hline Generated leachate & 134.8 & 8,087 & 39.4 \\
\hline
\end{tabular}




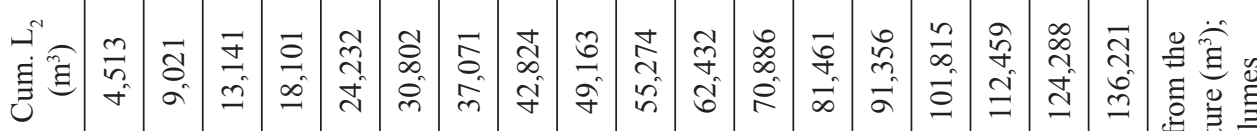

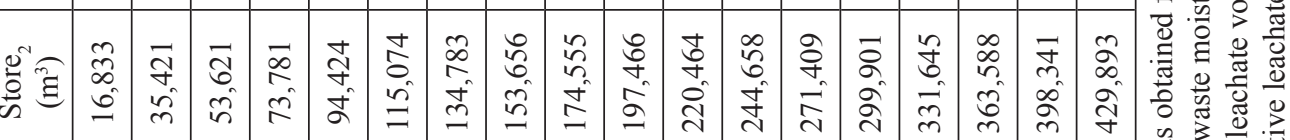

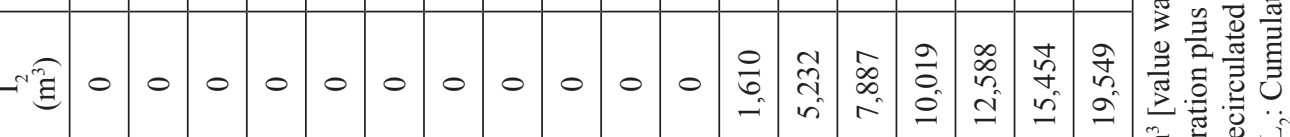

- $\infty$ م

$w^{2}$ 音 $\underset{\gamma}{\mathscr{\gamma}}$ 宇

च

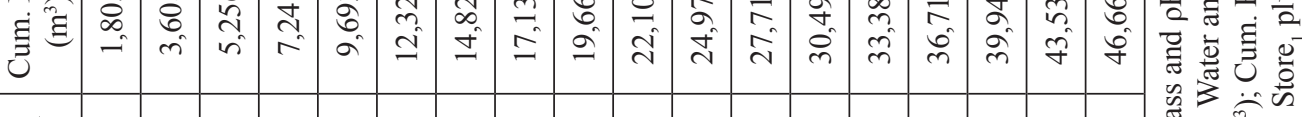

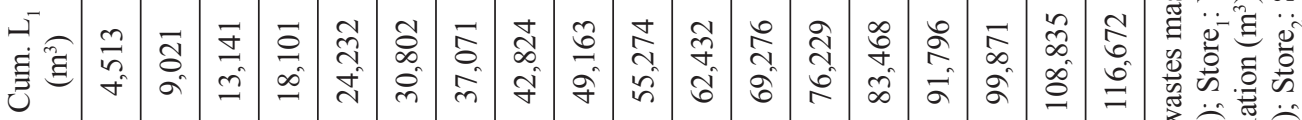

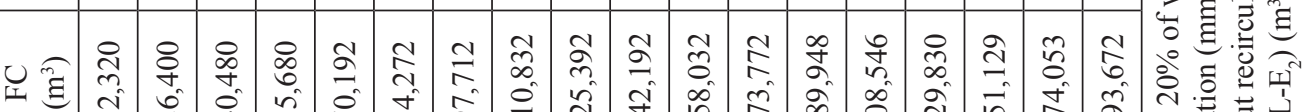

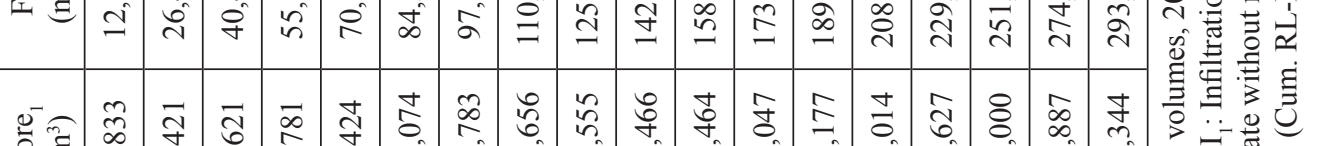

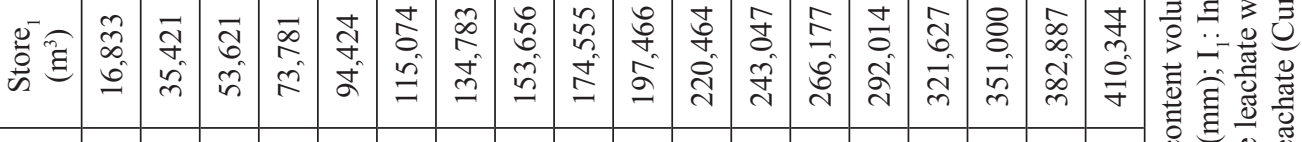

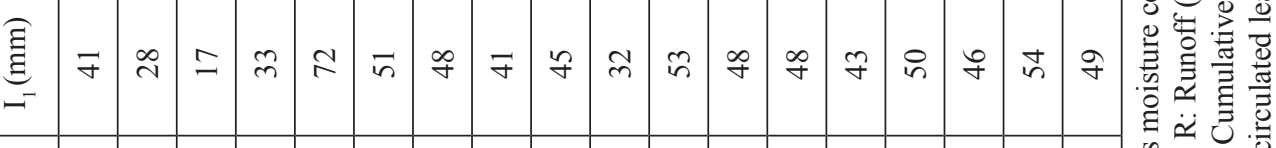

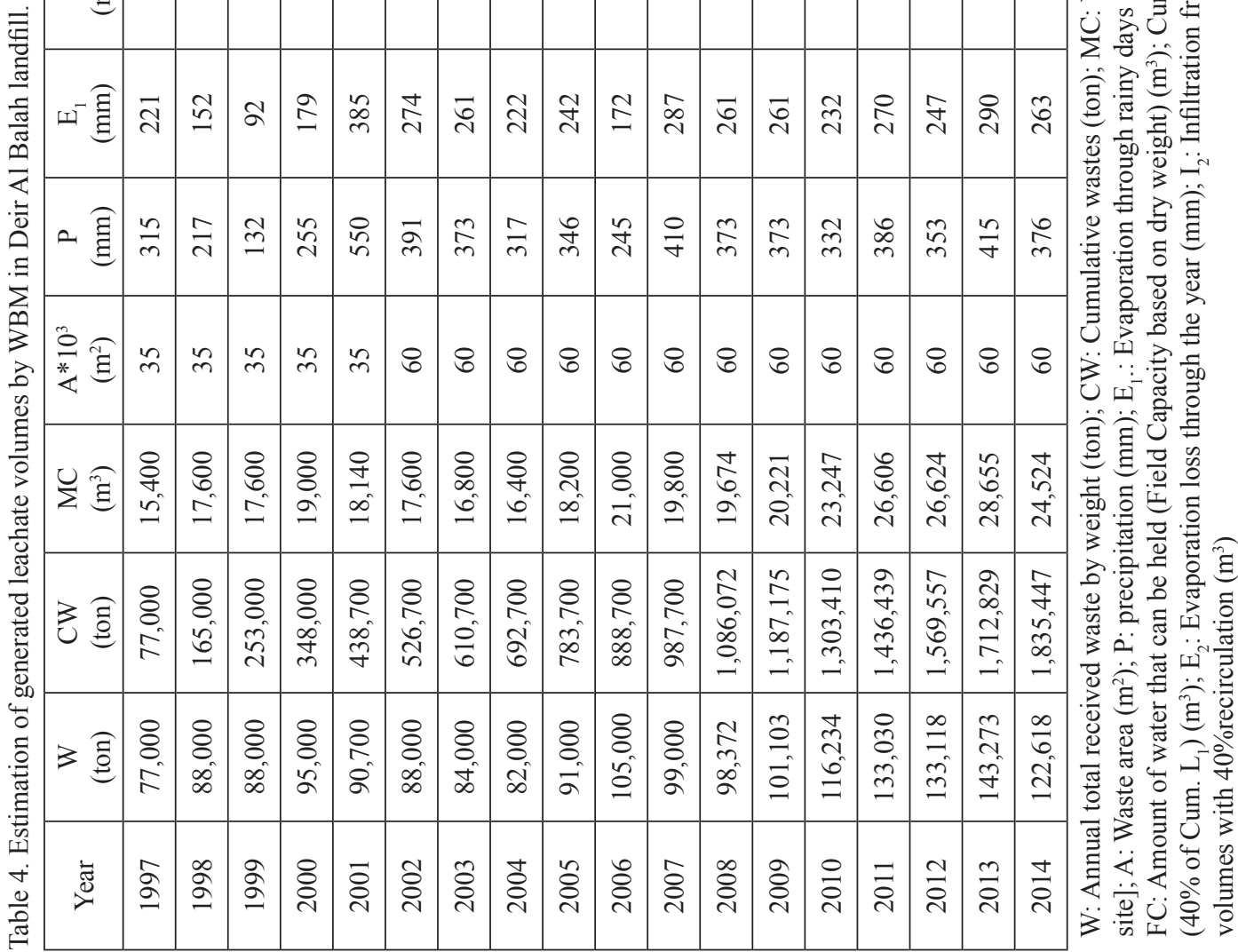

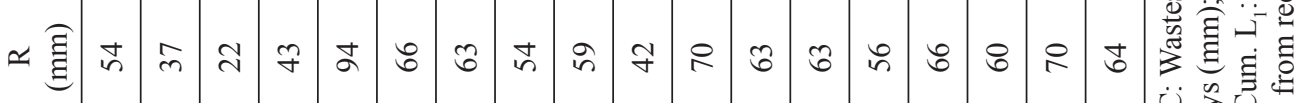


evapotranspiration volume was about $57.87 \%$ of rainfall in the period (1997-2007). In the end, the average percolated leachate through the final lining layer was $717 \mathrm{~m}^{3}$ year-1, which represents $8.9 \%$ of the generated leachate.

On the other hand, WBM calculations of the produced leachate volumes with $40 \%$ as a recirculation ratio during the same period are illustrated in Table 4 . The results of WBM showed that the average annual generated leachate were about 7,568 $\mathrm{m}^{3}$ (Fig. 2), for average annual dumped wastes of around of 101,969 tons. In addition, it revealed that the increase of annual dumped wastes leads to as increase of the annual generated leachate as a result of the high organic content in the dumped wastes, which represent about $60-70 \%[10,12-13]$.

The landfill's leachate originated from three main sources: precipitation, recirculated leachate, and initial moisture content of the dumped wastes. About 53.9\% of the leachate amounts originated from initial moisture content of the dumped wastes as estimated by WBM, whereas the remaining were derived from precipitation infiltration and recirculated leachate, with percentages of $31.8 \%$ and $14.4 \%$, respectively.

According to the landfill managers, the measurement of leachate quantities started from 2001 due to the absence of leachate measurement tools. Fig. 4 presents the cumulative measured leachate quantities at the site versus the estimated values by both HELP and WBM. The cumulative leachate volumes as estimated by HELP and WBM at the end of study period were $145,564 \mathrm{~m}^{3}$ and $136,221 \mathrm{~m}^{3}$, respectively. While the measured cumulative volumes by Deir Al Balah landfill management were about $114,351 \mathrm{~m}^{3}$. In addition, the cumulative percolated leachate through the landfill lining system in 2014 were $12,912 \mathrm{~m}^{3}$.

F-test was used to compare the variances among the two methods' results and the actual measured values by site management from 2001 to 2011. Both HELP and WBM results showed a low difference in estimating leachate quantities, as represented by F-value of 0.86 and a relatively high P-value of 0.4 .

However, the HELP model and WBM results showed relatively high variance rates compared with the measured leachate volumes of F-values equal to 1.58 and 1.85, and low P-values of 0.2 and 0.1 , respectively. This variance between both methods and measured data refer to errors in the measured leachate volumes.

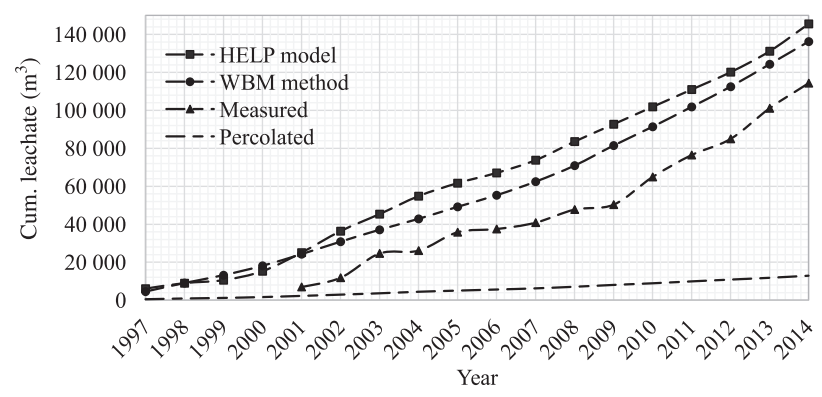

Fig. 4. Cumulative modelled and measured leachate volumes.
Moreover, the percentage difference test between the HELP model and WBM results of cumulative leachate amounts was $6.6 \%$, while between measured values and the used methods (HELP model and WBM) they were $24 \%$ and $17.5 \%$, respectively.

$$
\text { Percentage difference }=\frac{|H E L P-W B M|}{\frac{(H E L P+W B M)}{2}} * 100 \%
$$

In general, the cumulative leachate volumes by HELP indicated results close to WBM, while both methods estimated higher values than the measured leachate amounts at the landfill site (Fig. 4). These differences can be referred to the following points:

- HELP overestimates the generated leachate quantities as reported and established by different previous studies $[7,17]$. Therefore, HELP estimations were higher than both WBM and measured leachate amounts.

- The high moisture content in the dumped wastes was the main contributor to the calculated leachate volumes [9].

- The absence of accurate tools for measuring leachate volumes and using primitive methods to quantify leachate volumes at the landfill's site led to an error in the measured leachate amounts. Such methods included: human observation and mathematical estimations of the leachate quantity in the leachate ponds, leachate recirculation rates, pumping hours, etc.

- Part of generated leachate was accumulated and percolated through the lining system into the underling soil layers. Thus the measured leachate amounts at the site were lower than the modelled results.

\section{Conclusions}

In this study, the HELP model and WBM method were applied to evaluate the generated and percolated leachate amounts to the soil layers from Deir Al Balah landfill in GS/Palestine, which was facing real challenges regarding protection of its crucial groundwater resource from leachate contamination.

Generally, the cumulative leachate results as estimated by HELP and WBM through the study period showed that close results were $145,564 \mathrm{~m}^{3}$ and $136,221 \mathrm{~m}^{3}$, respectively, and with a percentage difference of $6.6 \%$. However, the cumulative measured leachate amounts at the landfill site were $114,351 \mathrm{~m}^{3}$, which were lower than the modelled amounts by HELP model and WBM by $24 \%$ and $17.5 \%$, respectively.

Since the landfill is located in a semi-arid and developing region, about $53.9 \%$ of produced leachate originated from the intimal moisture contents of the refused wastes, and about $53.8 \%$ of precipitation was lost as evapotranspiration. Moreover, about $8.9 \%$ of the generated leachate was percolated through the landfill's 
lining system toward the groundwater aquifer. Therefore, urgent intervention and mitigation measures should be applied to protect the groundwater aquifer.

\section{Acknowledgements}

The authors would like to acknowledge the University of Malaya research grant (FL001-13SUS) and the fundamental research grant by the Ministry of Higher Education (FP016-2014A) for financial support. We would like to thank UM Water Research Center for the support rendered to us. We are most grateful and would like to thank the reviewers for their valuable suggestions, which have led to substantial improvement of the article.

\section{References}

1. GRUGNALETTI M., PANTINI S., VERGINELLI I., LOMBARDI F. An easy-to-use tool for the evaluation of leachate production at landfill sites. Waste management, 2016.

2. MOR S., RAVINDRA K., DAHIYA R.P., CHANDRA A. Leachate characterization and assessment of groundwater pollution near municipal solid waste landfill site. Environmental monitoring and assessment, 118 (1-3), 435, 2006.

3. SINGH R.K., DATTA M., NEMA A.K. Review of groundwater contamination hazard rating systems for old landfills. Waste management \& research: the journal of the International Solid Wastes and Public Cleansing Association, ISWA, 28 (2), 97, 2010.

4. YANG N., DAMGAARD A., KJELDSEN P., SHAO L, HE P. Quantification of regional leachate variance from municipal solid waste landfills in China. Waste management, 46, 362, 2015.

5. EL-FADEL M., FINDIKAKIS A.N., LECKIE J.O. Modeling leachate generation and transport in solid waste landfills. Environmental technology, 18 (7), 669, 1997.

6. SCHROEDER P.R., MORGAN J.M., WALSKI T.M., GIBSON A.C. The hydrologic evaluation of landfill
Performance (HELP) model, volume I, user's guide for version 1. Cincinnati, US EPA, 1984.

7. BERGER K.U. On the current state of the Hydrologic Evaluation of Landfill Performance (HELP) model. Waste management, 38, 201, 2015.

8. ZHANG W., ZHANG G., CHEN Y. Analyses on a high leachate mound in a landfill of municipal solid waste in China. Environmental Earth Sciences, 70 (4), 1747, 2013.

9. ALSLAIBI T.M., ABUSTAN I., MOGHEIR Y.K., AFIFI S. Quantification of leachate discharged to groundwater using the water balance method and the Hydrologic Evaluation of Landfill Performance (HELP) model. Waste Management \& Research, 31 (1), 50, 2013.

10. Municipal Development and Lending Fund (MDLF). Environmental and Social Impact Assessment (ESIA) for Gaza Solid Waste Management Project, Municipal Development and Lending Fund, Gaza, Palestine, 2012.

11. ALQADER A.A., HAMAD J. Municipal solid waste composition determination supporting the integrated solid waste management in Gaza strip. International Journal of Environmental Science and Development, 3 (2), 172, 2012.

12. JABER A., NASSAR A. Assessment of Solid Waste Dumpsites in Gaza Strip. Environment Quality Authority (EQA) and Japan International Cooperation Agency (JICA), Gaza Strip, 15, 2007.

13. United Nations of Development Program (UNDP). Feasibility Study and Detailed Design for Solid Waste Management in the Gaza Strip, 2012.

14. German Technical Cooperation (GTZ). Annual report of solid waste management - Gaza middle area - Landfill design. Gaza Strip: Solid Waste Management Council, 2002.

15. SCHROEDER P.R., AMMON D.C. The hydrologic evaluation of landfill performance (HELP) model: user's guide for version 3. Risk Reduction Engineering Laboratory, Office of Research and Development, US Environmental Protection Agency, 1994.

16. JAGLOO K. Groundwater risk analysis in the vicinity of a landfill: A case study in Mauritius. Royal Inst. of Technology, 2002.

17. ALSLAIBI T.M. Evaluating the impact of landfill leachate on groundwater aquifer in Gaza Strip using modeling approach. MSc thesis, The Islamic University, Gaza, Palestine, 2009.

18. Palestinian Meteorological Office (PMO), Climate software data, Gaza, Palestine, 2014. 